\title{
Effectiveness of Electronic Government in the Citizen-Centric Approach in Bandung City
}

\author{
${ }^{1}$ ELISA SUSANTI, ${ }^{2}$ RIDHO HARTA, ${ }^{3}$ SYARIF FADILLAH \\ ${ }^{1}$ Universitas Padjadjaran, Jalan Raya Bandung-Sumedang Km. 21 Jatinangor, Indonesia \\ ${ }^{23}$ Universitas Terbuka, Jalan Cabe Raya, Tangerang Selatan, Indonesia \\ email: ${ }^{1}$ elisa.susanti@unpad.ac.id; ${ }^{2}$ ridho@ecampus.ut.ac.id; ${ }^{3}$ syarif@ecampus.ut.ac.id
}

\begin{abstract}
This paper aims to exploit e-government effectiveness from the perspective of users by focusing on online-based business licensing services in Bandung City. This paper also aims to develop the E-government Citizen Satisfaction Framework proposed by Sigwejo and Pather (2016). The method used is a qualitative method in e-government research. The results show that there is a gap between the services provided and community expectations. Online-based business licensing services in Bandung City have not been fully effective and also have not fully given the benefits since licensing is still one of the obstacles in conducting business in Bandung City. The main findings in this paper are the three themes as a development of the e-government effectiveness model, namely users' e-readiness, multi-channel delivery of e-government services, and the net impact. The implication of the main findings is that the integration of online services and offline services is required in accordance with the mapping of users' e-readiness.
\end{abstract}

Keywords: Citizen centric, E-government effectiveness, Multi-channel e-government

\section{Introduction}

Previous studies on the effectiveness of e-government have concentrated more on the supply side (government-centric) and only a few researches were carried out in developing countries from the demand side (citizen-centric) (Gupta, 2008; Otieno and Omwenga, 2015). The supply side of e-government consists of networks, platforms, devices, interfaces, and utilization infrastructure; while the demand side of e-government consists of citizens' and customers' values, needs, motivation, access, skills and patterns of behaviour (Anttiroiko, 2008). The citizen-centric approach is a citizen-centered approach, advocating the provision of services that meet the demands and expectations of citizens. (Jin-fu and Duo, 2009; Sigwejo and Pather, 2016).

In the case of e-government services in Indonesia, the assessment components considered relatively low are the Telecommunication Infrastructure Index and the Online Service Index (based on the E-Government Development Index).
Indonesia's ranking is still below the world average or even Southeast Asia. In economic terms, Indonesia's ranking in ease of doing business promoted to 72 in 2018 . Nevertheless, Indonesia's position is still below that of other ASEAN countries. Starting a business in Indonesia is still relatively difficult due to the length of time spent in registering a business (ranking 144th) which can take up to an average of 47 days. Based on the global competitiveness report, there are the most problematic factors in doing business in Indonesia. The first factor is corruption, and the next is inefficient bureaucracy as the second problem in doing business in Indonesia.

Economic area is one dimension of e-government. In economic areas, there is a Government to Business relationship. E-Government should promote productivity by reorganizing governmental internal operating processes based on smart technology (Kwon, 2014). Baharuddin (2015) also suggested that the transformation of licensing in the online form was done to facilitate an open interaction 
between the government and the community and to avoid illegal fees and gratuities.

Bandung as the capital of the province of West Java is one of a few cities that have implemented the concept of e-government in every aspect of government. Based on the ranking of e-Government Indonesia (PeGI), Bandung is ranked 4th as the best in West Java. Bandung also received an award in the 2017 Smart City Rating for Indonesia. One of the online services implemented by the Bandung city government is in the area of business licensing services which expected to increase the ease of doing business so as to increase economic growth.

Despite receiving various awards in e-government and smart city, several problems are still found in business licensing. The ranking of ease of conducting business in Bandung is still ranked 12th out of 20 cities in Indonesia. The results of Syafni and Adi's (2015) research on licensing in Bandung showed that applicants who expressed dissatisfaction with permit application services amounted to $11.29 \%$ in 2012 . There were also 440 complaints relating to improper processing of permit applications. Based on the performance report of BPPT (Agency for the Assessment and Application of Technology) Bandung, it is known that the achievement of the realization of the community satisfaction index in 2014 amounted to $83.28 \%$ which is not in accordance with the target of $85 \%$. Likewise, the Ombudsman version of the standard for public service compliance is 930, not in line with the target of 950.

Previous studies on e-government services were mostly done in a governmentcentric approach. From various studies, it is known that the implementation of e-government in Indonesia has not shown a positive trend in quality (such as Masyhur, 2017; Sari and Winarno, 2012). Some recommendations made are governmentcentric, namely commitment from the government, infrastructure development, human resources, training, application, regulation (Sari and Winarno, 2012; Huda \&Yunas, 2016; Hardjaloka, 2014), leadership, funding allocation (Huda \&Yunas, 2016), organization and work procedures (Hardjaloka, 2014). Rinaldi and Yuardani (2015) revealed that e-government in the presentation of data and information through the website is still dominated by the government and not directly related to community needs. Delone Mc Lean (2016) also argues that to date, there has been insufficient research from a citizen-centric approach. There is also no further research that focuses on developing e-Government success measures in terms of impact.

Therefore, this research is unique and different from previous studies. Research is rarely done on e-Government in Government to Business (G2B) relations to realize economic productivity. Previous research has also been carried out more in a governmentcentric approach, while this research will discuss e-government effectiveness from a citizen-centric approach. The e-government service in question is in the field of onlinebased business licensing that is associated with business convenience in Bandung.

Delone and McLean's information system success model $(1992,2003,2016)$ has been a valuable contribution to understanding the success of information systems and also the effectiveness of e-government. DeLone \& McLean (2016) suggested the term effectiveness has the same meaning as a success. There are several terms in evaluating the success of ICT use, such as assessment of ICT use (such as Viscusi et.al, 2010), information system success or information system effectiveness (such as Delone and McLean, 1992, 2003, 2016), e-government effectiveness (such as Sigwejo and Pather, 2016; Merhi, 2016), e-government service quality (such as Omar et.al, 2011; Hien, 2014), and also e-government acceptance (such as Sahu and Gupta, 2009; Fu et al., 2004).

The effectiveness of e-government assesses the extent to which e-government programs can achieve the mission and goals of the organization, as well as the quality of service and citizen satisfaction (Yang \& Rho, 2007). In the citizen-centric approach, Merhi (2016) proposed an e-government effectiveness model namely "The e-government rocket model" with five elements namely trust thrust engine, functionality, technology, efficacy, and enablers. Another approach put forward by Sigwejo and Pather (2016) regarding the E-government Citizen Satisfaction Framework. This framework is used to evaluate the effectiveness of e-government in a citizen-centric approach. E-government effectiveness is defined as citizen satisfaction. User satisfaction will appear if the services provided can exceed user expectations.

There are two objectives of writing this paper; the first is to explore e-government effectiveness from the citizen-centric approach of online-based business licensing services in 
Bandung. The second objective is to develop an e-government effectiveness model in a citizen-centric approach. The writing of this paper uses the Sigwejo and Pather (2016) model as guidance theory. There are five dimensions of this model, namely citizen expectations, facilitating conditions, intention to use e-government services, the use of e-government services and citizen satisfaction.

\section{Research Methodology}

This study uses a qualitative approach. This method can be used in evaluating the success of e-government. As stated by Sarker et.al (2013), there is an increase in the number of government and information systems research using qualitative methods. The reason for using qualitative methods in this research is based on the formulation of the problem which requires researchers to carry out various exploratory activities in order to understand a social situation about the expectations of users of online-based licensing services in Bandung. Citizencentric is related to citizens' values, needs, motivation, and patterns of behaviour.

These qualitative research steps are based on qualitative research methods by Creswell (2009) and qualitative data analysis for e-government research by Wimmer \& Bricking (2009). Placement theory in qualitative research is at the beginning of the study. At the end of the study, researchers modified the theories of Sigwejo and Pather (2016). Thus, the stages in this research include (1) determination of guidance theory at the beginning of the study; (2) data collection; (3) data validation; (4) analysis of qualitative data; (5) modification of the theory at the end of the study based on categorization/coding which is a new aspect in the research.

Research data obtained directly from the field through unstructured and semistructured interview techniques, as well as observation. Secondary data obtained through documentation and literature studies. There are two categories of informants in this study, namely informants from the Department of Investment and One-Stop Integrated Services (DPMPTSP) of Bandung City, and informants from the community applying for business licenses consisting of applicants for SIUP (Business License), TDP applicants (Company Registration Certificates), Location Permit Applicant, TDG (Warehouse Registration)
Applicant, IUTM Applicant, Travel Bureau Permit Applicant, and micro-small business licensing applicant. Criteria for determining informants are those who have gone through all stages of online-based licensing services.

Data validation is done by triangulation techniques using various sources. The steps of qualitative data analysis in this research include (1) Preparing the data for analysis (2) Categorizing data and coding according to the theme and data reduction. Data categorization and coding were conducted based on (a) Code based on the literature that has been prepared previously (guidance theory) (b) The code on themes is a new aspect of research. (c) Group which is a data reduction. Based on the results of coding, the theme is produced as the main finding in qualitative studies. (3) Creating narratives that describe themes and produce visualizations and theme lines to show the interrelations between themes. (4) Making data interpretations in the form of a comparison between field data and theory.

\section{Results and Discussion}

Based on the results of data collection, data validation, and categorization/coding, the resulting categorization is as shown in Table 1. Afterward, discussion of the effectiveness of e-government through the citizen-centric approach to online-based business licensing services in Bandung will be based on the categorization.

In table 1 , it can be seen that there are categories based on guidance theory and categories beyond guidance theory which are new aspects of the research. Each category consists of topics and dimensions. Topics are single aspects/problems, while dimensions are values variations consisting of two or more topics (Wimmer and Bricking, 2009). The categories are based on the guidance theory by Sigwejo and Pather (2016) with dimensions of citizen expectations, facilitating conditions, intention to use e-government services, use of e-government services, and citizen satisfaction. Based on the field results, new aspects of research were found that were grouped into categories outside the guidance theory. The new aspects mentioned are multichannel delivery of e-government services, users' e-readiness, and the net impact.

\section{E-Government Effectiveness by Guidance Theory Category (Sigwejo dan Pather, 2016)}

The first dimension, namely citizen 
Table 1

Categorization Based on Theme Codes in E-Government Effectiveness Based on Citizen-Centric Approaches for Online Based Business Licensing Services in Bandung

\begin{tabular}{lll}
\hline \multicolumn{1}{c}{ Categorization } & \multicolumn{1}{c}{ Note } \\
\hline \begin{tabular}{ll}
\multicolumn{1}{c}{ The functionality of e-government } \\
services
\end{tabular} & $\begin{array}{cl}\text { Citizen expectations } \\
\end{array}$ & $\begin{array}{l}\text { Categorization is based on the } \\
\text { theme code that the authors hope } \\
\text { to find based on the guidance } \\
\text { theory. }\end{array}$
\end{tabular}

Motivation to use e-government

services

Enabling

Facilitating Conditions

government infrastructure

preparedness

\author{
Intention to Use E-Government \\ Service \\ Use of E-Government Service \\ Citizen Satisfaction \\ Multi-channel delivery of Categorization is based on a \\ e-government services theme code which is a new \\ Users' e-readiness aspect of research (topics beyond \\ Net Impact \\ guidance theory)
}

Source: processed from qualitative data, 2019

expectation, is a high expectation for the services offered by the government which will be more helpful in meeting their needs better, faster, and more efficiently. Citizen expectation consists of two aspects. The first aspect is the performance of services which indicates how quickly service requests can be completed.

All types of permits in Bandung DPMPTSP are handled online through the GAMPIL application (Gadget Application Mobile for License) or through the Website. The online licensing workflow at DPMPTSP starts with creating the applicant's account and submitting the permit service request by filling out the requirements form in the application. The next stage is administrative verification, validated by the Head of District, and continued to the technical team. If the recommendation is accepted, it will be followed by the approval of the Head and the applicant can immediately pay the levy and fill out the IKM (community satisfaction) survey. Next is the signing, printed, and sent via POS (postal). That is a flow which generally accepted for all types of licensing.

There are two views from the public regarding service performance. At first glance, it is assumed that through online licensing, services are more quickly completed. Most of the informants stated that they felt they were helped by online licensing, were quickly resolved, were easily accessible, and could cut transportation costs. The informant said that he got the service in accordance with the procedures, conditions, time, and costs that have been determined. Another informant stated that: "Since there was an application, I felt it was helpful in taking care of licensing. If there was a file of requirements that had not been fulfilled, I used to have to incur enormous costs because the place of business was far from DPMPTSP. With the application, I can simply download the application to take care of a business license. When it's finished, 2-4 days later the POS (Postal) delivers the permission to the address that has been listed."

The second view suggests that the timeliness of services has not gone well, not in accordance with the service target. Based on the Standard Operating Procedure, the period of electronic licensing service up to the signing of the new permit and non-permit documents is set at a maximum of 7 working days, and for permits and non-permits other than new applications are set at 4 working days. A small number of informants stated that they waited too long for the permit file, and this permit could not be done offline. The informant stated: "I have been waiting 
for 6 months. I have asked directly but it has not yet been published". Another informant stated: "When I have registered the file, I could not continue to the next stage because the data has not entered the database yet, so I waited too long".

Based on informants from DPMPTSP, the community still lacks understanding of the time frame for online licensing completion. What the applicant does not know is that the 7-day work process is calculated from the payment stage and also the IKM assessment (community satisfaction survey). The process depends on how long the applicant pays retribution and completes the IKM survey. In addition, the stages of the technical team are not included in the count of 7 working days because licensing can be stopped for months.

Regarding the issue of delays in issuing permits, several informants noted that they had difficulty in obtaining permits related to the district. The informant stated: "I am tired of having to go back and forth to the district since there is always something missing. It would be alright if I'm not working, but $I^{\prime} m$ a working person and the sub-district services must be done during working hours which make it more difficult for me." There were several obstacles in the verification process in the sub-district to the validation team. Delay is also caused by the lack of coordination with the POS. There are permit documents that have been completed but are piled up and delivered late by the POS. The informant stated: "I did not receive the letter in a timely manner because there was a miscommunication between the postal and DPMPTSP." In this case, service delays are indeed related to interoperability. The informant from DPMPTSP stated that: "indeed there are still some internal constraints, such as lack of coordination between teams which causes delays in the issuance of permits. In handling the permit process, DPMPTSP performs in accordance with applicable regulations. If it does not match, it will be rejected or stopped."

With online services, it is hoped that services will be conducted faster, easier, and cut bureaucratic structures. But the wish of the applicant to harmonize all services from various agencies has not yet been fully realized. There were many complaints related to the process in the technical and management team in the District.

The second aspect of citizen expectation is people's motivation to take advantage of e-government services considered beneficial. Based on Sigwejo and Pather (2016), this motivation includes trust in e-government, ease of use, perceived benefits and adequate expertise to manage e-government. In the aspect of trust in e-government over online services, most respondents said they believed in data security. Likewise, data access for the government can only be done by IT staff. Through online licensing, the public recognizes that it is more transparent, there are file monitoring, and complaints are always responded to. There were no complaints from informants related to illegal payments. Nevertheless, based on observations, there were still brokers in the licensing process.

Furthermore, there are two views from the community related to aspects of ease of use. The first glance considers the application easy to use and understand. The informant stated: "We can see what requirements which automatically appear on the application, so there is no need to ask DPMPTSP again. The regulations are also stated in the application." Another informant stated: "The content makes it easy for me to register an application. Just choose the type of licensing, see the terms and procedures. The applicant can check to what stage the licensing process has been. If there are complaints, you can directly contact the call centre in the form of a telephone number or complaint feature. While the second view suggests that not all people understand the use of online licensing applications. The informant stated: "The licensing service did not really help me because it was not as easy as with a tax permit." Another informant stated: "For those who are technology literate, it seems easy. But for me as a layman, I do not necessarily know the process, and it will be difficult to understand. In fact, there are still many people who are confused". Online licensing has not been widely understood by the public despite the socialization and announcement. People who want to extend their business licenses are confused because they were previously done offline.

The second dimension of guidance theory based on Sigwejo and Pather (2016) is facilitating conditions, which are defined as the extent to which government infrastructure and preparedness support e-government services. Based on the results of interviews, the most common complaints raised were unstable network infrastructure and no Hotspots available at DPMPTSP. The informant stated: "Internet connection is one of the classic problems faced in government circles. 
Indeed, network disruptions often occur, but these problems can be quickly resolved."

Moreover, the aspect of government preparedness is the extent to which the government is ready to serve its constituents in the digital age, including policy support. Online licensing services are regulated in (1) Presidential Regulation No. 97 of 2014 concerning the Implementation of One-Stop Integrated Services which explains that licensing by PTSP is required to use online services. (2) Licensing in Bandung City is regulated in Mayor Regulations Number 855 of 2015. For the future, regarding Government Regulation No. 24 of 2018 concerning electronic business licensing services (Online Single Submission), the Gampil application owned by the Bandung City Government will be integrated with the OSS application.

The informant from DPMPTSP stated that: "There are various legal bases in e-government and services. These various legal bases are listed on the website and on the bulletin boards." It was further stated that "the Government of Bandung City strongly supports e-government policies which can be seen from various applications. For the future, regarding OSS (Online Single Submission), Bandung City has also made preparations that can be a model for other cities." Funding for online systems has been budgeted for infrastructure, the making of applications, and also websites. Website development has been started since 2008 until now. Other developments such as the institutional development of DPMPTSP were also carried out including training the apparatus.

The next dimension of guidance theory is the intention to use, which is the desire of the community to re-utilize e-government services. There are two views in this dimension. The first view is, in general, the people of Bandung that appreciate online services but still want better online services. The second view is people who prefer offline services. Some informants stated that they would or would not want to use this online service because they needed a business permit. They prefer offline services and are assisted by DPMPTSP officers. Another informant stated that although everything had to be done online, in its implementation, the community still went to the agency to directly deliver various complaints.

The next dimension of guidance theory based on Sigwejo and Pather (2016) is the use of e-government service. In this dimension, the government must learn to attract and retract citizens by making them interested in e-government services. Most of the informants stated that they might be happier with online services if there were continuous improvements in the system and improvement of complaints from the public. Some things that people complain about are applications and networks that often experience errors, difficulty in logging in, and failure to upload requirements. The numbers of other applicants who also register through this application make the application run slow; it also often logs out by itself and start over. The website does not yet support the community because there is no save data option so that if there is a lack of conditions and/or errors, the community should start from scratch.

\section{Effectiveness of e-Government Based on New Aspect Categories beyond the Guidance Theory}

The analysis of qualitative data resulted in categories of new aspects beyond the guidance theory from Sigwejo and Pather (2016). The new aspects are multi-channel delivery of e-government services, users' e-readiness, and net impact.

The first new aspect is about the multi-channel delivery of e-government services. Based on the previous interview, it is known that there are people who prefer offline services. Some complaints related to online services can be explained by Fan \& Yang (2015), stating that there are different perceptions from the community. Before using online services, people used offline services. After online services being introduced, people choose it mainly because of their expectations over this new way. However, in the implementation, there are some obstacles so that people prefer to go back to offline services again.

Comparing to the State service commission of New Zealand (2006), the characteristics of e-government services in New Zealand are a comfort, satisfaction, and give freedom to choose service channels. The State Service Commission of New Zealand (2006) stated that: "Government is not just about technology. It gives people more choices, makes them more productive, and allows them to interact with government in a way that is convenient for them and respects their privacy." Regarding various service options based on public convenience, United 
Nations (2012) suggests that the delivery of multichannel services is the provision of public services in various ways. Citizens can make choices according to their needs which in turn would increase their satisfaction and trust in the government. Traditional channels include offline service with face-to-face contact, e-mail, or telephone. Digital channels include websites, mobile-based services, and public access. The government can also use virtual networks managed by the private sector or non-governmental organizations.

The second new aspect is users' e-readiness. Some general indicators in e-readiness including ICT infrastructure, human resources, law, and regulations, have been stated by Sigwejo and Pather (2016) through the facilitating conditions dimension. However, the results of interviews in the field found that there were some informants who felt unfamiliar with the technology so that they preferred the offline service. The findings in the field are in line with what was stated by Viscusi et.al (2010) that the new model in e-readiness is to add consideration to the user's socio-economic composition. Some aspects that need to be considered in users' e-readiness are age, gender, and residence (such as city/rural), level of education and cultural capital, socio-economic position, family composition and position of individuals in the family. The reading of this user's character will lead to the provision of special services in accordance with the conditions of the user/community.

The third new aspect is the net impact. The phenomenon in the field shows that e-government effectiveness does not only stop at the output but also on a further aspect, namely benefits or impact. As it is stated by Yang \& Rho (2007), e-government evaluation must be based on potential expected benefits, such as citizen satisfaction, economic competitiveness, transparency, efficiency, and effectiveness. Scott et al. (2011) suggested net impact as public values in understanding e-Government success.

Innovations in business licensing are made to facilitate businesses in Bandung. Based on the results of interviews, it is known that most of the informants did not experience obstacles in doing business, and most of the other informants stated they still encountered various obstacles in doing business in Bandung. Of the various barriers to business, the biggest obstacle faced by businesses in Bandung is a licensing problem. This indicates that online services cannot be fully felt by business actors. Some other problems related to doing business in Bandung are capital constraints, problems of business security, problems of business competition, and others.

Based on data from the Central Statistics Agency, the economic structure of the City of Bandung is dominated by 6 categories of business. Among the six business fields, wholesale and retail trade, car and motorcycle repair, and manufacturing are the business sectors that play the highest role in the total GDP of Bandung. However, despite its high role, during 2013-2017, those business fields tended to show a declining pattern of roles. During 2017, there was an economic growth of 7.21 percent, slower than the previous year's economic growth which reached 7.79 percent. From these conditions, it can be seen that although the Bandung city government has made various efforts of innovation in business licensing, some business actors still say there are obstacles in licensing, as well as the economic growth of Bandung which has slowed down. It means that the net impact of online business licensing has not yet been fully achieved.

This phenomenon can be referred to as the statement of the World Bank (2002) saying that "the essence of e-government is not just giving computers or automating old practices. However, the use of technology must be able to increase greater effectiveness in services". E-Government in Bandung seems to be more to the transfer of forms from offline to online by building many applications. But the essence of e-government to change the process faster, easier, simpler, less/ not complicated, is not yet fully felt by the community. Thus, the net impact of online business licensing has not yet been fully achieved.

\section{Development of e-Government Effectiveness Models}

Based on the Sigwejo and Pather (2016) categories and categories that are new aspects of research, the authors visualize the model of e-government effectiveness through the citizen-centric approach in figure 1 .

In this model, there are three dimensions of the Sigwejo and Pather (2016) model development. The three dimensions are users' e-readiness, multi-channel delivery of e-government services, and net impact. Users' e-readiness is an aspect of e-readiness 


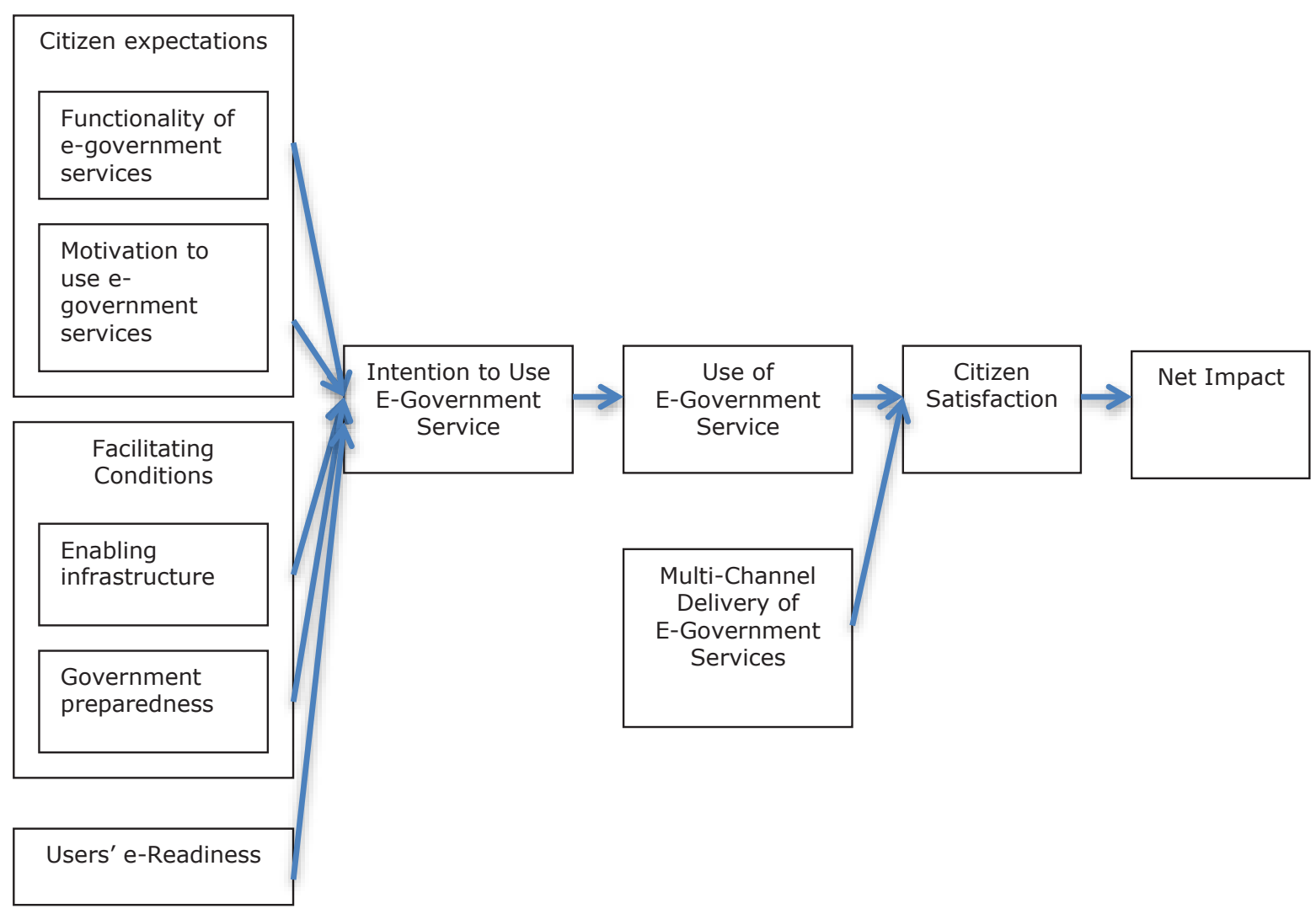

Figure 1. Visualization of E-Government Effectiveness Models in a Citizen-Centric Approach Based on Sigwejo and Pather (2016) and New Findings in Qualitative Analysis

that adds consideration to the user's socioeconomic composition. This dimension together with facilitating conditions will determine the intention to use e-government service. Furthermore, multi-channel delivery of e-government services is the use of various channels, namely traditional channels, digital channels, and public access. Consideration should be given to the use of various channels according to the convenience and needs of the community. In the case of business licensing services in Bandung, it is necessary to consider the integration of online and offline services. Next is the net impact, which is the final point of effectiveness. This net impact is a public value, an expected benefit. The net impact in the case of online business licensing services is ease of business and economic competitiveness.

\section{Conclusions}

The effectiveness of e-government in the citizen-centric approach is interpreted as the extent to which e-government services can meet the expectations of the community.
Based on the citizen-centric approach, e-government in online-based business licensing services in Bandung has not been fully effective, which means there is still a gap between the services provided and people's expectations. Online services are believed to provide benefits; however, there are several obstacles in the implementation. Some of the unfulfilled public expectations from online-based business licensing services in Bandung are related to interoperability with hopes for simpler service procedures and better coordination between agencies, improvement of network infrastructure, more detailed website content, and faster handling of complaints. Regarding the various obstacles in online services, there are other aspects related to community expectations, namely people who prefer offline services because not all people understand online services. Furthermore, the phenomenon in the field also shows that online-based business licensing services in Bandung have not fully met the benefits because licensing is still one of the obstacles in doing business in Bandung.

Based on this, there are three new 
aspects as the development of e-government effectiveness models in the view of citizencentric. The three aspects are users' e-readiness, multi-channel delivery of e-government services, and net impact. To achieve e-government effectiveness, users' socio-economic considerations are needed. Consideration is also needed to use various channels in e-government services. In the case of online-based business licensing services in Bandung, it is necessary to integrate online services and offline services. Related to the three aspects in developing the e-government effectiveness model, the suggestion for further studies is that further assessment is needed on users' e-readiness for online-based services. Further study is also needed on the integration of online services and offline services.

\section{References}

Anttiroiko, A.V. (2008). Electronic Government: Concepts, Methodologies, Tools, and Applications. United States of America : Information Science Reference

Baharuddin (2015). Akuntabilitas Pelayanan Publik : Studi Kasus Pelayanan Perizinan Mendirikan Bangunan di Kota Makassar. MIMBAR, Vol. 31, No. 2 (Desember, 2015): 263-270

Creswell, J. W. (2009). Research design: Qualitative, quantitative, and mixedmethod approaches. California: Sage

DeLone, W.H. \& McLean, E.R. (1992). Information systems success: The quest for the dependent variable. Information Systems Research, 3(1):60-95, 1992

DeLone, W.H. \& McLean, E.R. (2003). The DeLone and McLean model of information systems success: A ten-year update. Journal of Management Information Systems, 19(4):9-30, 2003.

Delone, W.H. \& McLean, E.R. (2016). Information Systems Success Measurement. United States: now Publishers Inc.

Fan, J. \& Yang, W.(2015). Study on E-Government Services Quality: The Integration of Online and Offline Services. Journal of Industrial Engineering and Management, 2015 - 8(3): 693-718

Fu, J. R., Chao, W. P., \& Farn, C. K. (2004). Determinants of taxpayers' adoption of electronic filing methods in Taiwan: An exploratory study. Journal of Government Information, 30(5-6), 658-683.

Gupta, D.N. (2008) Citizen-Centric Approach for e-Governance. In Argawal, A., and
Ramana, V.V. (Eds). Foundations of e-Governance: Proceedings of the 5th International

Hardjaloka, L. (2014). Studi Penerapan e-Government di Indonesia dan Negara Lainnya Sebagai Solusi Pemberantasan Korupsi di Sektor Publik. Jurnal RechtsVinding, Vol 3 No. 3, Desember 2014.

Hien, N.M. (2014). A Study on Evaluation of E-Government Service Quality. International Journal of Social, Behavioral, Educational, Economic, Business and Industrial Engineering Vol:8, No:1, 2014

Huda, M. \&Yunas, N.S. (2016). The Development of e-Government System in Indonesia. Jurnal Bina Praja 8 (1) (2016): 97-108

Jin-fu, W. \& Duo, H. (2009) Customercentered E-government Service Quality Evaluation: Framework and Case Study. In Luo, Q., Yi, J. and Bin, C. (eds). ISECS International Colloquium on Computing, Communication, Control, and Management, Sanya, China, 8-9 August. Piscataway, NJ: IEEE. Vol. 3: 198-202.

Kwon, G.H (2014). E-Government \& E-Strategy. SKKU-Samsung Foundation: Publishing Company

Masyhur, F. (2017). Penelitian e-Government di Indonesia: Studi Literatur Sistematis dari Perspektif Dimensi Pemeringkatan e-Government Indonesia (PeGI). IPTEKKOM, Vol. 19 No. 1, Juni 2017: 51-62

Merhi, M.I. (2016). E-government effectiveness: a rocket model of contributing user-related factors. International Journal Services and Standards, Vol. 11, No. 1, 2016.

Omar, K., Scheepers, H \& Stockdale, R. (2011). E-Government Service Quality Assessed through the Public Value Lens. IFIP International Federation for Information Processing 2011.

Otieno, I. \& Omwenga, E. (2015). CitizenCentric Critical Success Factors for the Implementation of E-Government: A Case Study of Kenya Huduma Centres. Journal of Emerging Trends in Computing and Information Sciences. Vol. 7, No. 2, February 2016

Rinaldi, H \& Yuardani, A.M (2015). Analisis Peluang Transformasi "E-Government" Menjadi "E-Democracy" Melalui Website Pemerintah Daerah. MIMBAR. Vol. 31, No. 1 (Juni 2015) : $103-112$

Sari, K.D \& Winarno, W.A. (2012). Implementasi e-Government System dalamUpayaPeningkatan Clean and Good Governance di Indonesia (Implementation 
of e-Government Systems in Efforts to Improve Clean and Good Governance in Indonesia). JEAM Vol XI No. 1/2012

Sahu, G.P \& Gupta, M.P (2009). Users' Acceptance of E-Government: A Study of Indian Central Excise. In Khosrouw-Pour. (Eds)E-Government Diffusion, Policy, and Impact: Advanced Issues and Practices. United States of America : Information Science Reference

Sarker, S., Xiao, X., \& Beaulieu, T. (2013). Qualitative Studies in Information Systems: A Critical Review and Some Guiding Principles. MIS Quarterly Vol. 37 No. 4 pp. iii-xviii/December 2013

Scott, W., DeLone, \& Golden. (2011). IT quality and e-government net benefits: A citizen perspective. In European Conference on Information Systems, Helsinki, Finland, 2011

Sigwejo, A. \& Pather, S.(2016). A CitizenCentric Framework for Assessing E-Government Effectiveness. The Electronic Journal of Information Systems in Developing Countries. EJISDC (2016) $74,8,1-27$

State service commission New Zealand. (2006). Enabling transformation: a strategy for e-government 2006. Wellington, New Zealand: State service commission
Syafni, H.R. \& Adi, T.N (2015) Arsitektur Aplikasi Berbasis Service Oriented Architecture pada Badan Pelayanan Perizinan Bidang II Kota Bandung (Service Oriented Architecture Based Application Architecture in Licensing Services Sector II in Bandung). e-Proceeding of Engineering: Vol.2, No.1 April 2015

United Nations (2012). Supporting multichannel service delivery. United Nations E-Government Survey 2012

Viscusi , G., Batini , C.\&Mecella . Massimo. (2010). Information Systems for e Government: A Quality-of-Service Perspective. London: Springer

Wimmer, M.A \& Bicking, M (2009). Qualitative Data Analysis of Issue Interrelations and Interdependencies for E-Government Research Planning. In Wimmer et.al. (Eds). Electronic Government. 8th International Conference, EGOV 2009 Linz, Austria, August 31 - September 3, 2009 Proceedings

World Bank (2002). The E-Government Handbook For Developing Countries. Center For Democracy \& Technology.

Yang, K \& Rho, S.Y. (2007). E-Government for Better Performance: Promises, Realities, and Challenges. International Journal of Public Administration, 30: 1197-1217, 2007 